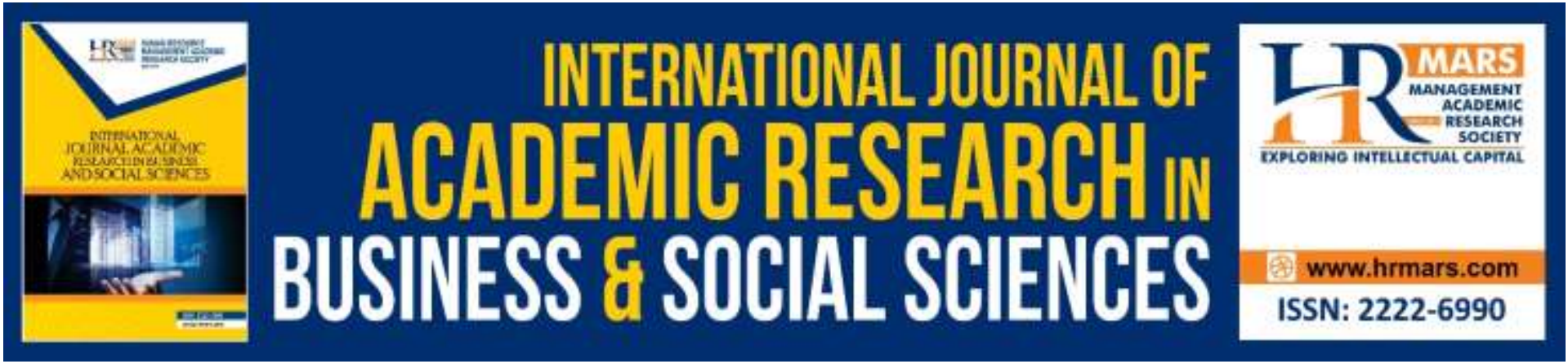

\title{
A Critical Analysis of Terengganu Rural Transformation Centre
}

\section{Norsuhaily Abu Bakar, Ibrahim Mamat, and Wan Musa Wan Muda}

To Link this Article: http://dx.doi.org/10.6007/IJARBSS/v9-i11/6612

DOI: $10.6007 /$ IJARBSS/v9-i11/6612

Received: 10 October 2019, Revised: 30 October 2019, Accepted: 03 November 2019

Published Online: 13 November 2019

In-Text Citation: (Bakar, Mamat, and Muda, 2019)

To Cite this Article: Bakar, N. A., Mamat, I., and Muda, W. M. W. (2019). A Critical Analysis of Terengganu Rural Transformation Centre. International Journal of Academic Research in Business and Social Sciences, 9(11), 930-941.

\section{Copyright: (C) 2019 The Author(s)}

Published by Human Resource Management Academic Research Society (www.hrmars.com)

This article is published under the Creative Commons Attribution (CC BY 4.0) license. Anyone may reproduce, distribute, translate and create derivative works of this article (for both commercial and non-commercial purposes), subject to full attribution to the original publication and authors. The full terms of this license may be seen at: http://creativecommons.org/licences/by/4.0/legalcode

\section{Vol. 9, No. 11, 2019, Pg. 930 - 941}

Full Terms \& Conditions of access and use can be found at http://hrmars.com/index.php/pages/detail/publication-ethics 


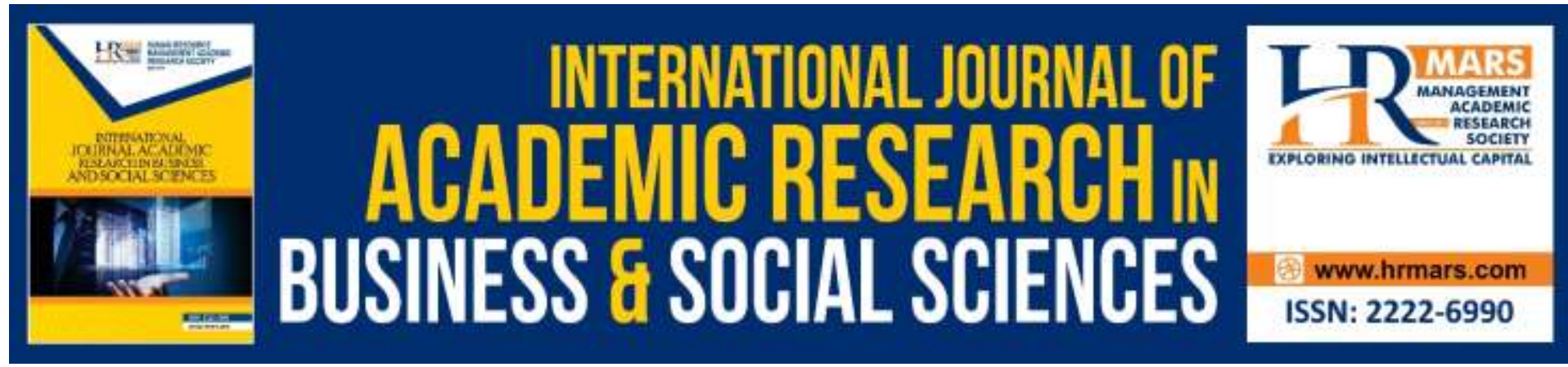

\title{
A Critical Analysis of Terengganu Rural Transformation Centre
}

\author{
Norsuhaily Abu Bakar, Ibrahim Mamat, and Wan Musa Wan \\ Muda
}

Universiti Sultan Zainal Abidin, Kampus Gong Badak, 21300 Kuala Nerus, Terengganu.

Email: norsuhaily@unisza.edu.my

\begin{abstract}
The rural population is expected to be more viable and able to compete through the establishment of Rural Transformation Center (RTC). In addition, the RTC is also expected to help increase the income and living standards of the rural population such as marketing their products across the country and penetrating the export market. It can also focus on changing the minds of the people, not just serving them. This study uses a qualitative approach by interviewing five informants who have the credibility of obtaining complete information on the governance, issues and challenges faced by RTC Terengganu. The findings evidenced that the establishment of RTC Terengganu basically encouraged rural people to become entrepreneurs but business operations and activities at the RTC were monopolised by a subsidiary of the Central Terengganu Development Authority (KETENGAH). It also faces the problem of lacking support where most agencies do not receive the welcome of the locals. Among the proposals are purification related to RTC governance, strategic networks and population development needs.
\end{abstract}

Keywords: RTC Terengganu, Rural Product, Service

\section{Introduction}

Transformation means changing the nature or appearance, shape and other changes (DBP, 1992). In Malaysia, transformation is often associated with development due to economic growth (Miskam \& Shafii, 2013). The RTC's Introduction to Rural Transformation (RTC) by the Malaysian government is to implement various RTC initiatives in an integrated manner under the approach of the National Blue Ocean Strategy 4 (NBOS4). This center is supporting the realisation in the potential of rural areas generating economic growth by focusing on value-added and high-income sectors. Therefore, RTC focuses on nine initiatives: (a) skills training for rural people, (b) establishment of 1Malaysia information kiosk, (c) high value agriculture, (d) Agrofood product processing, (e) (f) university cooperation, (g) food security and pharmaceutical services, (h) financial facilities for rural residents and (i) agro-tourism (Mamat, 2012).

In order to ensure RTC is able to provide the best services to the rural population, management personnel need maximum training before assuming responsibility. 
According to Zaidatol et al. (1998) many programmes implemented by the government did not achieve the objective because the responsible party lacked the skills or knowledge on the needs of their target groups. The government's development in rural areas was aimed at bringing the villagers into the mainstream but was unable to improve the quality of their lives. The concept of development is the process of change from the initial stage to a more advanced state either in terms of human, physical or environmental thinking. The concept of development encompasses four components that the government needs to achieve: (a) efficiency (ensuring rapid economic growth), (b) equitable distribution of wealth in the country (covering poverty eradication and reducing income disparity gaps), (c) development now does not threaten the lives of future generations), and (d) the empowerment of the people, especially vulnerable groups such as the poor. Therefore, development is one of the government's efforts to reduce poverty, inequality and unemployment in the context of a growing economy.

In fact, in the history of world development, the community has undergone a number of sudden changes in the process known as the paradigm shift. The change which uses the word 'waves', says the world has wiped out three waves of revolution, namely: (a) agriculture, (b) industry, and (c) information / information. This wave of change has eight megatrends that are transforming the economy, government and culture of Asia and forming a Commonwealth country to compete with western power and influence. Among the eight megatrends are: (a) nations to networks, (b) traditions of choice, (c) export guidance to consumer encouragement, (d) government control to market stimuli, (e) (f) intensive labor intensity to high technology, (g) male empowerment to female emergencies, and ( $h$ ) changes from west to eas

Thus, the wave of development is not only focused on developed countries, but also involves developing countries as science and communication technology has grown rapidly so that megatrends occur worldwide and become a 'Global Village' (Ohmae, 1985). However, development by the Malaysian government using the RTC approach not only serves the rural population, but also involves a mentality transformation program. The RTC approach approximates the recommendations of the United Nations through Agenda 21 in Rio De Janeiro, Brazil. This principle calls for the community, the people and the rulers together play an important role in the management of the environment and development. Therefore, the government should recognise a way that allows multiple parties to effectively engage in achieving sustainable development. Hence, at local levels such as Local Authorities, NonGovernmental Organizations (NGOs), stakeholders and communities have a role to play in balancing the development infrastructure, economy, people and the environment.

Principle 22 of Local Agenda 21 (LA21) Rio de Janeiro, 1992, calls for the community of people and rulers to co-exist and play an important role in environmental management and development. The Government shall recognise in an appropriate manner to enable effective participation of various parties in achieving sustainable development. Hence, locally, Local Authorities, non-governmental organizations (NGOs), stakeholders and the people play a role in balancing the development of infrastructure, humans and the environment. The LA21's basic approach is the bottom-up approach. This means local people themselves will be involved in 
determining their respective action plans. For example, locals are directly involved in discussions, workshops or activities related to local issues.

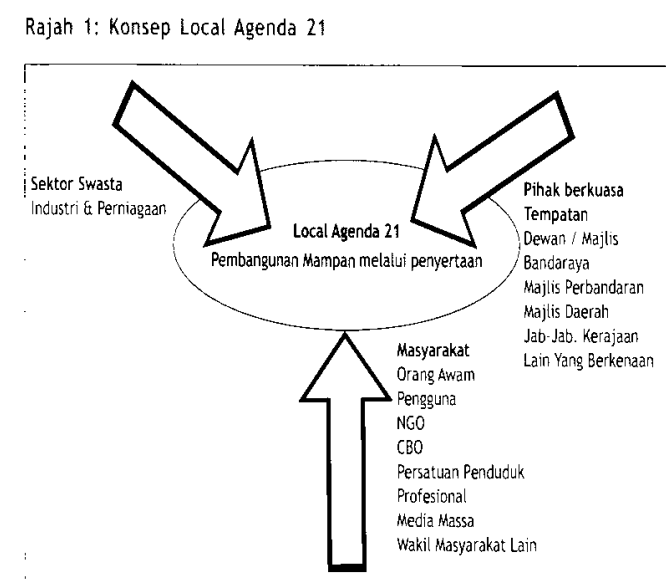

Webster \& Muller (2000) highlighted four areas: economic structure, human resources, provincial physical endowment and city governance as a major component of urban competitiveness. This opinion is in line with other scholarly views such as Linnamaa \& Sotarauta (1998) identifies the elements of infrastructure, firms, public institutions, the environment of competence and human capital as a determinant of the city's competitiveness. Infrastructure elements include transportation and ICT (computer \& information technology) to increase the accessibility of places, residents, goods and services, and further expand the market. Morsidi (2005) in his study in Malaysia also pointed out that a competitive city should have four factors: innovative economic resources, skilled labor, physical capability and efficient urban governance.

\section{RTC Governance}

Bandar Gopeng in Perak is the first area in Malaysia to have the RTC launched by Prime Minister Dato 'Seri Haji Mohd Najib bin Tun Haji Abdul Razak on 18 February 2012 [3]. The government has plans to launch RTCs to all states across the country to improve the living conditions of rural people living in the area around a radius of 100 kilometers from the center. The RTC concept seeks to provide benefits to the rural population for enabling them to receive various government services, explore business opportunities and access the necessary information in a single premise. The government creates a unique platform to combine all activities and gather almost all agencies dealing with rural people to provide them with better service. However, the success of the RTC depends largely on the activities carried out at the center.

Therefore, in order to ensure that governance practices can be carried out properly, it is essential that an organisation such as the RTC Terengganu has a structured organisational structure so that the tasks and responsibilities can be implemented more efficiently and effectively. The organisational structure enables better human resources to be managed. Since RTC Terengganu has just been created by the government, this study has the following objectives: (a) examining the suitability of governance; and (b) identify the issues and challenges of Terengganu RTC. 


\section{Research Methodology}

This study uses a qualitative approach to interview five informants who have the credibility of obtaining complete information on the governance, issues and challenges faced by RTC Terengganu. In the first stage, the researchers interviewed two officers and three workers who were directly involved in the establishment and experience of Terengganu RTC operations. They were selected for having information on RTC Terengganu. Furthermore, this method of study was qualitative that required deeper information about governance RTC Terengganu. Kumar et al. (1993) says that the selected informants must have the knowledge, ability and willingness to communicate on the issues being studied. Semi-structured questionnaire guides have been developed and used to assist the informal interview process in depth. In the second stage, the researchers held several focus group discussions involving agency staff and premise tenants within the Terengganu RTC complex. The information obtained from this method outlines the issues and challenges surrounding Terengganu RTC. According to Bilson (1989) focus group discussions not only help researchers to understand what the informants think, but even understand their thinking patterns.

Field data collection has been made for three months from February to April 2015. Data collected through interviews and focus group discussions has been analysed using content analysis methods that are considered suitable for qualitative research. Conversation, treatment, observation, document and interpretation is analysed to determine the meaning of a phenomenon. All recorded and written data are finally compiled according to themes and categories. Formulating several themes and categories in content analysis are commonly used for qualitative research. Each theme explains a phenomenon related to research questions. When the category is formed some themes can illustrate a phenomenon more thoroughly.

\section{Development Requirement Analysis \\ Descriptive Analysis: General}

An analysis of the development needs is an attempt to identify the gap between what exists and what should be. Residents are required to list the various services required and determine the level of satisfaction for the service. This analysis uses data collected from 285 respondents interviewed using the questionnaires. The result of the requirement analysis can be used to make project planning to develop the target group.

\section{Trustworthiness Test}

The reliability test was performed on all the data obtained to prove that the questions in the identified variables were accurate. This test uses the average value of Alpha Cronbach. The reliability test was broken down by the variables namely the compliance factor, trust, reliability, response, and customer satisfaction level.

As suggested by Sekaran (1992) the measure of reliability is able to show how far this question is free from bias and hence ensuring consistent size among the items in that field. The reliability test results below than 0.6 can be classified as weak. Results within 0.7 are acceptable and more than 0.8 are considered to be good. Based on this 
interpretation, the reliability of this research is acceptable. Table 2 below provides a summary of the reliability tests that have been conducted

Table 1: Alpha Cronbach Alpha Coefficients

\begin{tabular}{|l|l|l|}
\hline Variable & $\begin{array}{l}\text { Total } \\
\text { item }\end{array}$ & $\begin{array}{l}\text { AlphaC } \\
\text { ronbac } \\
\text { h } \\
\text { Averag } \\
\text { e Value }\end{array}$ \\
\hline $\begin{array}{l}\text { Section D: Effectiveness of } \\
\text { Terengganu RTC }\end{array}$ \\
\hline $\begin{array}{l}\text { Location and } \\
\text { Arrangement of } \\
\text { RTC Terengganu }\end{array}$ & 5 & .728 \\
\hline Infrastructure & 5 & .841 \\
\hline Service & 4 & .830 \\
\hline Promotion & 14 & .830 \\
\hline Premise Rental & 6 & .942 \\
\hline $\begin{array}{l}\text { Price of Goods } \\
\text { and Quality }\end{array}$ & 4 & .958 \\
\hline Public & 4 & .903 \\
\hline $\begin{array}{l}\text { Section E: Analysis of } \\
\text { Development Requirements }\end{array}$ \\
\hline Importance & 30 & .908 \\
\hline Satisfaction & 30 & .936 \\
\hline
\end{tabular}

Table 1 shows the number and percentage of respondents who have ever been to RTC. Overall, 236 or 82.2 percent of respondents have stated that they have been to RTC. Meanwhile, 51 of the 287 respondents have never been to RTC located in Durian Mas, Terengganu.

Table 2 : RTC visits

\begin{tabular}{|lll|}
\hline \multicolumn{2}{|c|}{ Yes/No } & Total Percentage \\
Respondent & \\
\hline Yes & 236 & 82.2 \\
No & 51 & 17.8 \\
\hline Total & 287 & 100.0 \\
\hline
\end{tabular}

Of the 287 respondents, 89 persons or 31 percent who had been to the RTC were from the customer category. Meanwhile, the second majority is from the category of staff or RTC agency, which is 56 persons or 19.5 percent. Tourist and tourist categories are 43 and 1

This tourist category is a person who lives far away from the RTC and comes only once for a reason to stop over this category of visitors has come several times but has no 
business in RTC. The minority category is from the category of wholesalers, tenants or traders, farmers and laborers ie the number of respondents recorded is 7, 2 and 1 respectively.

During this study, problems related to inconsistency in the operation of each agency located in RTC Terengganu are still occurring and may affect the role of the RTC as a one-stop service center. The various problems faced by the agencies located in RTC Terengganu are shown in Table 4.

Table 3: Number and Percentage of Respondents by Category

\begin{tabular}{|lll|}
\hline $\begin{array}{l}\text { Respondent Category } \\
\text { Respondent }\end{array}$ & $\begin{array}{c}\text { Total } \\
\text { Percentag } \\
\text { e }\end{array}$ \\
\hline $\begin{array}{l}\text { Office / Agency } \\
\text { RTC Staff }\end{array}$ & 56 & 19.5 \\
Seller & 2 & 0.7 \\
Retail Shoppers & 37 & 12.9 \\
Wholesaler & 7 & 2.4 \\
Customer & 89 & 31.0 \\
Visitors & 43 & 15.0 \\
Farmers & 1 & .3 \\
Labor & 1 & .3 \\
Tourists & 2 & .5 \\
Never been but & 50 & 17.4 \\
knows about RTC & \\
\hline \multicolumn{3}{l}{} \\
\hline Total & 287 \\
\hline
\end{tabular}

Table 4: List of agencies located in RTC Terengganu and issues

\begin{tabular}{|l|l|}
\hline \multicolumn{1}{|c|}{ Agency } & \multicolumn{1}{c|}{ Issues } \\
\hline $\begin{array}{l}\text { National } \\
\text { Department }\end{array}$ & $\begin{array}{l}\text { - There is no identification card printing machine. } \\
\text { - Not getting the list of assets from RTC for } \\
\text { audit objectives. } \\
\text { - Slow maintenance and no office damage } \\
\text { completed by the RTC. }\end{array}$ \\
\hline $\begin{array}{l}\text { Immigration Department of } \\
\text { Malaysia }\end{array}$ & -No Problems \\
\hline $\begin{array}{l}\text { Department of Nephrology } \\
\text { (Hemodialysis Center) }\end{array}$ & - Serves only 28 patients. \\
\hline Rehabilitation Centre & $\begin{array}{l}\text { - No operating approval. } \\
\text { - On-off service. } \\
\text { - Approval of operation required to place } \\
\text { officers and staff. }\end{array}$ \\
\hline
\end{tabular}




\begin{tabular}{|c|c|}
\hline $\begin{array}{l}\text { Food Safety and Quality } \\
\text { Division (MUST) }\end{array}$ & $\begin{array}{l}\text { - Just need to place a clerk to keep the premise when an } \\
\text { employee works outdoors. }\end{array}$ \\
\hline $\begin{array}{l}\text { Department of Veterinary } \\
\text { Services (JPV) }\end{array}$ & $\begin{array}{l}\text { - The interviewed representative said he would move } \\
\text { If office rental in the RTC is enforced. } \\
\text { - He has dismissed an allocation of RM500 thousand for } \\
\text { buying a building because of the RTC lobbying to } \\
\text { operate in RTC for free. } \\
\text { - He felt agonised because the promise is not fulfilled. }\end{array}$ \\
\hline $\begin{array}{lr}\text { Community } & \text { Development } \\
\text { Department } & \text { (KEMAS) } \\
\text { (Focus: Stitch Class) }\end{array}$ & $\begin{array}{l}\text { - Their office is in the top level } \\
\text {-Problem arises in terms of transporting goods (the majority } \\
\text { of them are women). } \\
\text { - Little allowance (only for teachers only). } \\
\text { - No provision of cloth, yarn or other apparatus. } \\
\text { - No basic help such as allowance for student, cloth, threads } \\
\text { and sewing needs. }\end{array}$ \\
\hline $\begin{array}{l}\text { Majlis Amanah Rakyat } \\
\text { (MARA) }\end{array}$ & $\begin{array}{l}\text { - The MARA system is not accessible to create loan, payment, } \\
\text { check loan balance and etc. } \\
\text { - Required to issue a payment receipt manually and officers } \\
\text { are forced to go to Dungun branch for business payment due } \\
\text { to lack of bank service. }\end{array}$ \\
\hline Tekun Nasional & $\begin{array}{l}\text { - Internet access is problematic. } \\
\text { - Unreliable aspects of RTC safety. } \\
\text { - National TEKNIC did not dare to risk placing valuables such } \\
\text { as computers and other equipment at RTC. }\end{array}$ \\
\hline $\begin{array}{lr}\text { Federal } & \text { Agricultural } \\
\text { Marketing Authority (FAMA) }\end{array}$ & - Not situated in RTC. \\
\hline $\begin{array}{l}\text { The Malaysian Co-operative } \\
\text { Societies Commission (SKM) }\end{array}$ & $\begin{array}{l}\text { a.- Do not have permanent staff at RTC. } \\
\text { - Operates on event only. }\end{array}$ \\
\hline
\end{tabular}

Table 4: List of agencies located in RTC Terengganu and issues (continued)

\begin{tabular}{|c|c|}
\hline Agency & Issues \\
\hline $\begin{array}{l}\text { Family } \quad \text { Development } \\
\text { Foundation (YPK) }\end{array}$ & $\begin{array}{l}\text { - No bank facilities causes aid channels to local people not } \\
\text { being implemented smoothly. } \\
\text { - No permanent staff. } \\
\text { - Being on the RTC on-off due to absence of staff . YPK staff } \\
\text { is present at office only when there is an event in the RTC. } \\
\text { - More operations are concentrated in the Dungun branch. }\end{array}$ \\
\hline $\begin{array}{l}\text { Entrepreneur Development } \\
\text { Foundation (YPU) }\end{array}$ & $\begin{array}{l}\text { - No promotion. } \\
\text { - Suggested that the promotion / the existence of the RTC are } \\
\text { issued through radio and television broadcasts. }\end{array}$ \\
\hline Community College & - No Issues \\
\hline
\end{tabular}




\begin{tabular}{|c|c|}
\hline $\begin{array}{l}\text { Multiple Agency } \\
\text { Counters } \\
\text { a) MPK } \\
\text { b) MPD } \\
\text { c) MDHT } \\
\text { d) PDTK } \\
\text { e) PDTD } \\
\text { f) PDTHT }\end{array}$ & $\begin{array}{l}\text { - Different systems between agencies are problematic } \\
\text { for the officer to set up the system at the counter. } \\
\text { - Internet access issues. } \\
\text { - Off-site / administration functions and no benefits } \\
\text { can be given to residents because of the operations under } \\
\text { KETENGAH. }\end{array}$ \\
\hline KH Shop & - No Issues \\
\hline COOP 1 Malaysia Store & $\begin{array}{l}\text { - No promotion. } \\
\text { - Lack of respons. }\end{array}$ \\
\hline Fatisha Mushroom Kopitiam & - No Issue \\
\hline $\begin{array}{l}\text { Surada Jaya Sdn. Bhd. } \\
\text { (store) }\end{array}$ & - No customers if there is no programmes \\
\hline $\begin{array}{l}\text { Surada Jaya Sdn. Bhd. } \\
\text { (office) }\end{array}$ & - No Issues \\
\hline $\begin{array}{l}\text { AMBS Baby Centre } \\
\text { (Private) }\end{array}$ & $\begin{array}{l}\text { - No bus facilities. } \\
\text { - Propose in opening a business in the form of small kiosks to } \\
\text { attract people to visit RTC. }\end{array}$ \\
\hline RTC Administrative Center & $\begin{array}{l}\text { - No Promotion } \\
\text { - No Response. }\end{array}$ \\
\hline
\end{tabular}

\section{Terengganu RTC Challenge}

In Terengganu RTC complex there are more than 20 government agencies and NGOs.In addition, there are four premises inhabited by a subsidiary of KETENGAH Holding, an RTC administration center, a COOP 1 Malaysia store and two business companies. However, there are two agencies that the government has withdrawn from serving at the Terengganu RTC, FAMA and the Malaysian Cooperative Commission. The study also found that eight agencies operating in RTC Terengganu namely the District and Land Office of Dungun, District and Land Office of Hulu Terengganu, District and Land Office of Kemaman, Hulu Terengganu District, Dungun Municipal Council, Kemaman Municipal Council, National Tekun and Family Development Foundation have experienced handling electronic application system to channel their services to surrounding people. At the same time, MARA has provided services to the surrounding residents manually to address the problems of electronic application systems. Whereas, the National Registration Department started operating in the RTC since 2005 and received an application to make less identification card because there are not many residents living around the Al-Muktafi Billah Shah City .

In addition, this study found that Terengganu's RTC management has not maintained and coordinated efficiently with all government agencies, NGOs and private-owned businesses despite being under one roof. They should operate as a team. In fact, there are complaints from several government agencies as they have not been provided with the list of assets for audit purposes, no invitation to meetings, neglecting appointments such as rental premises exclusions, electrical overhaul and cleaning of office areas. In addition, there are also several agencies such as the Family Development Foundation, Malaysian Communication Commission, FAMA and Tekun 
Nasional who feel they have no need to operate in RTC Terengganu as the branches in Dungun provide better service.

Meanwhile, the state government should also take note of the management in RTC Terengganu which was handed over to KETENGAH. This study found that there were some management issues that causes dissatisfaction among tenants. Mainly, shop lots in the community market, especially in the early stages of the establishment given to the KETENGAH subsidiary. This is not in line with the RTC's goal of giving space and opportunity to local entrepreneurs. Second, the orchid center established in RTC Terengganu is also considered a waste of space. The third issue is that KETENGAH does not provide security systems which is justified because only one KETENGAH employee carries out the Terengganu RTC area. The security aspect of the agency's physical / government office space is also not taken seriously as there is no door-to-door grille, fire extinguisher and closed-circuit television (cctv).

The study found that some agencies such as the Department of Agriculture and FAMA who should operate in RTC Terengganu did not locate their offices. Thus, the absence of these two agencies affected RTC Terengganu to implement nine holistic initiatives such as high value agricultural projects and food product processing. These initiatives should be in the Terengganu RTC complex to assist farmers. The focus group discussions also found that most agency staff did not live up to the goals of the Terengganu RTC. It is no wonder that agencies intends to get out of Terengganu RTC complex. Conclusively, they do not understand the roles and contributions that can be given to the locals via RTC Terengganu.

Why do some of the above issues still exist in RTC Terengganu? Why most agencies still work solo while in the original concept of RTC Terengganu states that they should work together and make a steady stream of work to help the rural population? This continues as the Terengganu RTC complex is created in a hurry. All agencies involved are not provided with clear courses or explanations on the original concept of Terengganu RTC, coordination between KETENGAH and the united state government, the role of KETENGAH subsidiaries and state governments, especially UPENT, is unclear. At the same time, some KETENGAH subsidiaries are given the opportunity to trade monopolies and these advantages have blocked the target group to compete in a healthy way. Therefore, when agencies face problems, they are not sure where to complain.

\section{Suggestions and Conclusions}

The development of the AMBS area needs a balance that uses the economy capital-people economy approach. Capital brought from outside need to be utilised to develop local human resources for the success of all economic sectors. All the resources available in Terengganu RTC areas such as natural wonders, forest resources, local skills and heritage, all touch points (mini RTC and small towns) should be identified and developed. The involvement of all parties, especially the private sector, NGOs and the local community, should be shaken by the concept of partnership in development.

All agencies involved can not work in solo. Instead they need to work together in planning and implementing all projects and services for local communities. How they 
can work together and establish connectivity to foster all touch points should be discussed among agencies operating RTC through laboratories .

A close collaboration between Ketengah (RTC Terengganu governing body) and ECER for local development needs to be established. Among the possible joint venture projects is the development of 2 nd generation entrepreneurship and other life-long education projects for the development of surrounding families.

RTC Terengganu is not developed because of the lack of residents living around it. Strategies need to be formulated to enliven the population in the district of Besut. Nowadays, the population does not increase due to the problem of obtaining land for housing. No newcomer to build houses. The area also has no new housing parks developed by the private and government sectors. Most land administered by Ketengah causes the developer to face problems to develop a residential estate. It is proposed that the state government identify some areas around AMBS to be developed as a residential area to encourage the growth of the population around AMBS. The widest space and opportunity should be opened to encourage residents to move and settle in areas around the city of AMBS. The next strategy is to formulate the synergy of urban growth between Bukit Besi, Ketengah Jaya, AMBS, Pasir Raja and surrounding towns.

All Government agencies located in the RTC need to provide maximum level of facilities to be in line with the Government's vision through the Blue Ocean Strategy (NBOS) so that rural communities benefit better. Agency selection to be placed in the RTC should be an agency that can fully meet the needs of rural communities.

The RTC management should always organise various activities such as exhibitions of economic activities, in particular involving trading activities involving agricultural, fishery, livestock and related products in AMBS City. Apart from that, various other activities such as carnival career, expo, program for youths / friends and other activities can also attract people to the RTC. These activities need to be done systematically to ensure that the number of visitors to the RTC increases continuously. Priority should be given to entrepreneurs among the nearby villagers. This initiative is in line with the RTC's goal of closing the income gap of the villagers and successful cities. 


\section{References}

Miskam, N. \& Shafii, H. (2013). Transformasi Pembangunan Luar Bandar: Kesan Ke Atas Kesejahteraan Hidup Masyarakat, Universiti Tun Hussein Onn Malaysia.

Mamat, I. (Jan 2012). Faktor Penentu Tahap Kesukarelawan dalam Kalangan Belia Berpersatuan di Malaysia. Biayaan Institut Penyelidikan Belia Malaysia, KBS. Laporan dikemukakan kepada Kementerian Belia dan Sukan.RM 30,000. 115 muka surat.

Akmaliah, Z., Pihie, L., Konting, M. M., Bakar, A. R. \& Genevieve, A. (1998). Dasar Dan Strategi Program Peningkatan Keberkesanan Pendidikan Keusahawanan Untuk Abad Ke 21. Paper presented at Seminar Pendidikan Keusahawanan: Pendidikan Keusahawanan Abad Ke-21. Selangor, Malaysia.

Ohmae, K. (1985). Triad Power: The Coming Shape Global Competion. New York: The Free Press

Webster, D. \& Muller, L. (2000) Urban competitiveness assessment in the Developing Countries Urban Regions: The road forward. Paper Prepared for Urban Group. INFUD.World Bank, Washington DC.

Linnamaa, S. (1998) Urban competitiveness and management of urban policy networks: some reflections from Tempere and Ulu, Paper presented in Conference Cities at the Milleneum. OECD.

Sirat, M. (2005) Urban competitiveness and liveability in the Malaysia context: indicators, determinant and policy making. Kertas Kerja yang dibentangkan dalam Konvensyen Kebangsaan Hari Perancang Bandar Sedunia. JPPD \& Pertubuhan Perancang Malaysia, Kuala Lumpur. 17-18 November.

Kumar, N., Stern, L. W., \& Anderson, J. (1993).Conducting interorganizational research using key informants.Academy of Management Journal, 36(6), 1633 -1651.

Bilson, J. M. (1989). Focus Group: A Practical Guide for Applied Research, Clinical Sociology Review: Vol. 7 : Iss 1, Article 24.

Sekaran, U. (1992). Research Methods for Business: A Skill Building Approach. ${ }^{\text {nd }}$. Ed. John Wiley \& Sons Inc. USA 